\title{
Biological, Nutritional and Economic Benefits of Cassava-Maize-Bean Intercropping in Kirimiro and Mumirwa Agro-ecological zones, Burundi
}

\section{SIBOMANA Rémy ${ }^{* 1}$, KABONEKA Salvator ${ }^{2}$, BAKUNDUKIZE Nadine ${ }^{1}$, NIYONKURU Deogratias ${ }^{1}$, BUZOYA Elie ${ }^{1}$, BUKOBERO Libère ${ }^{1}$, HARIYONGABO Hormisdas ${ }^{1}$}

\author{
${ }^{1}$ Support for Integral Development and Solidarity in the Hills (ADISCO), Haguruka People's University (UPH). P.O
} Box 2695, Bujumbura, Burundi.

${ }^{2}$ Faculty of Agriculture and Bio-Engineering, Department of Environment Sciences and Technologies. University of Burundi. P.O. Box 2940 Bujumbura, Burundi

\begin{abstract}
Cassava (Manihot esculenta Crantz)-maize (Zea mays L.)-bean (Phaseolus vulgaris L.) intercropping system is common in Burundi. Nevertheless, despite the undeniable predominance of varied intercropping systems in the current Burundi agriculture landscape, national research programs remain focused on monoculture systems. The global objective of this investigation initiated by ADISCO/UPH was to evaluate the comparative advantages of the cassava-maize-bean intercropping system, relative to corresponding monoculture systems under two major Burundi agro-ecological zones, Kirimiro and Mumirwa. The two cropping systems were assessed on their effects on soil fertility, land equivalent ratio (LER), area x time equivalent ratio (ATER), nutrient value (energy, proteins) and economic benefits (total and net returns, value/cost). The study revealed that cassava-maizebean intercropping resulted in greater biological land-use efficiency $(+55 \%)$ and an increase in soil fertility parameters $(\%$, $\% \mathrm{~N}, \mathrm{CEC}$, exchangeable $\mathrm{Ca}^{2+}$ and $\mathrm{Mg}^{2+}$ ). Above all, compared to monoculture systems, the gains in energy (kilocalories) associated with the intercropping system varied between $+36 \%$ (Kirimiro) and $+59 \%$ (Mumirwa), while those of protein $(\mathrm{kg})$ content ranged from $+28 \%$ to $+51 \%$, respectively in Kirimiro and Mumirwa. However, the economic efficiency based on the value/cost ratio was low for both cropping systems (V/C=0.6-1.3). From this study, it is transparent that for most farmers, obtaining a well-balanced and regular diet for their family is more meaningful than any other intercropping benefits. In this context, it is more than urgent to find the right crop combinations that would yield better and, at the same time, produce a reasonably well-balanced diet. We then conclude that the development and dissemination of such cropping systems, appropriate to the Burundi rural reality, adapted to climate change, while meeting the nutritional and economic requirements for farmers is, with no doubt the today major challenge for agronomists, extensionists and policymakers alike.
\end{abstract}

Keywords: Cassava, Maize, Bean, Intercrop, LER, ATER, Energy, Proteins, Profitability.

\section{INTRODUCTION}

In Burundi, increasing and agriculture-dependent population (90\%) dramatically affect cropping land availability [1]. Cultivated land per household decreased from 1 ha in 1973, 0.7 ha in 1989 to only 0.5 ha in 2009, which comes to halfing cropping surface in 25 years [2]. At this trend, cultivated land per household could be projected to be around 0.25 ha in another 25 years.

Because most of the land for agriculture use is already exploited, more food should come from higher production on land already under cultivation, through increased number of crops produced per year on the same piece of land (intensification). This is multiple cropping which can be double (maize-bean, banana-bean), triple (banana-maizebean, cassava-maize-bean) or more complex (banana-cassava-maize-bean; cassava-maize-soybean-cowpea) [3]. Cereal-legume systems are the predominant cropping system in Burundi, in East Africa and in so-called developping countries for a number of reasons [4-13]. For example, in Northeast Brazil, cassava (Manihot esculantum Crantz) is often grown in two or three associations mostly with bean (Phaseolus vulgaris L.) and maize (Zea mays L.) for the 
following multipurposes: (i) reduce the risk of harvest loss following rainfall deficit; (ii) improve intensive use of small land area and family labor force; (iii) provide higher income and diversified nutrients [14]. In response to growing population in these regions of the world, increasing food production often on limited land constitues a challenge for agriculture technicians and policy makers [15].

Bean (Phaseolus vulgaris L.) is the most important grain legume in Burundi with annual production of 300,856 MT per year. Similarly, maize (Zea mays L.) and cassava (Manihot esculenta Crantz) are respectively the most grown and productive cereal (193,441 MT per year) and starchy crops (2,300,316 MT). These three crops represent two thirds of the total cereal equivalent (EC) of the food consumption per year in the country in the following proportions: $41 \%$ for cassava, $16.5 \%$ for bean and $10.4 \%$ for maize [2].

According to Andrews and Kassam (1976) [16], intercropping is a «crop management system involving two or more economic species grown together for at least a portion of their respective production cycles and planted sufficiently close to each other to allow interspecific interactions to occur ». Such systems are widespread among subsistence farmers under tropical zones in general [17, 18] and particularly in Burundi [2]. Even so, they rarely meet the interest of the scientific agriculture world because wrongly qualified and considered as archaic $[15,18]$. Surprisingly, the first registered interest of the scientific community on multiple cropping was the symposium on Multiple Cropping in 1975 at the annual meeting of the American Society of Agronomy in Knoxville, Tennesse [17]. Since then, research on multiple cropping has brought together ecologists, agronomists and social scientits because this research field is and should rightly be farmer-targeted and farmer-centered [19].

Intercropping is attractive to ecologists for its biodiversity and biological stability. Equally attractive to agronomists and physiologists because of its valorization of natural resources $\left(\mathrm{CO}_{2}, \mathrm{H}_{2} \mathrm{O}\right.$, nutrients) throughout the year while protecting soils against erosion, runoff and leaching. Economists value multiple cropping due to its time stability of production and spreading family income throughout the year and risks avoidance, as the agriculture enterprise is subject to vagaries of abiotic (rainfall, temperature) and biotic (pests and diseases) factors [17]. Multiple cropping is a way to increased land productivity by optimizing seasonally underemployed labor or capital resources and exploit biological complementarities (e.g. $\mathrm{N}_{2}$ fixation), resulting from the association of various crop species, either spatially or temporally [20]. The systems appear to be low input, yield and economy risk-reducing approaches, allowing crop diversification and fulfillment of subsistence agriculture common in many developping countries in terms of food security and well-balanced diet [21]

Unless there is a revolutionary socio-economic mutation, intercropping systems will continue to dominate the Burundi small scale agricultural landscape as households have limited land resources [15]. In this context, it is rewarding to find the right crop combinations that would yield well and, at the same time, produce a reasonably well-balanced diet. Development of such cropping systems adapted to climate change while meeting the nutritional and economic requirements for Burundi populations is, with no doubt the today major challenge for agronomists, extensionists and police makers [22]. Despite the undeniable predominance of varied intercropping systems in the actual Burundi agriculture landscape, national agronomic as well as breeding programs remain focused on monoculture systems.

As ADISCO/UPH is working together with farmers, its research team is able to get better understanding of what he is facing and from there mutually come up with practical and consensual solutions. The principal motivation of this investigation comes from the empirical observation that a significant proportion of Burundian farmers relies on multiple cropping for their food security and nutrition. Through indigenous know-how transmitted from generations to generations, it is apparent that Burundian farmers adopted often complex cropping systems and combinations which require a better understanding of their functionning and rationale. Burundi scientists have the responsibility to evaluate and improve them if needed [17].

An example of such complex cropping systems is the cassava-maize-bean intercropping for which, to our knowledge, beyond few agrarian qualitative descriptions [23-25], no other such investigation has been carried out yet within the Burundi agriculture sector. Thus, the global objective of this investigation was to evaluate the comparative advantages of cassava-maize-bean intercropping system, relative to corresponding monoculture systems under two major Burundi 
agro-ecological zones (AEZ), Mumirwa and Kirimiro. Specifically, the two cropping systems (CS) were assessed on their effects on soil fertility, biological efficiency, nutrient value (energy, proteins) and economic benefits (total and net returns, value/cost ratio $-\mathrm{V} / \mathrm{C})$.

\section{MATERIALS AND METHODS}

\subsection{Sites description}

The study was conducted on plots provided by selected collaborative and progressive farmers in Kirimiro and Mumirwa agro-ecological zones. Both sites are characterized by a bimodal rainfall distribution with a long rainy season from february to may and a short rainy season from september to december. The two rainy seasons are separated by a short dry season from mid-december to mid-january, and a long dry season from june to august. Mean annual rainfall is $932 \mathrm{~mm}$ in the Mumirwa site and $1,527 \mathrm{~mm}$ in the Kirimiro site. Average annual temperature is respectively $24^{\circ} \mathrm{C}$ in Mumirwa and $21^{\circ} \mathrm{C}$ in Kirimiro [26].

\subsection{Soils}

Soil samples were collected before field planting and after the completion of the study. Samples were randomly collected throughout the fields, bulked, dried and analyzed for \% organic C, \% organic N, Cation Exchange Capacity (CEC) and exchangeable cations $\left(\mathrm{Ca}^{2+}, \mathrm{Mg}^{2+}\right.$ and $\left.\mathrm{K}^{+}\right)$. Chemical analyses were performed by the Burundi Agriculture Research Institutes (ISABU) Soil Cares Laboratory by NIR Alpha and XRF spectrometers. Cation exchange capacity (CEC) and exchangeable cations were extracted with hexaminecobalt trichloride solution and determined by ICP-MS validated accordance ISO 23470:2007. Percent $\mathrm{C}$ was determined by combustion method in accordance NENEN15936:2012. Percent N was determined by Dumas method in accordance NEN-EN16168:2012. Results of the soil chemical analyses are shown in Table 1.

\subsection{Planting materials and fertilization}

Crop varieties used are those recommended by ISABU research in the particular agro-ecological zones: Muhoro (1,200-1,500 m, $2.25 \mathrm{~T} / \mathrm{ha})$ for climbing beans, ZM 605 (1,200-1,800 m; 3.5-4.5 T/ha) for maize in Kirimiro, ECAVEL 1 (800-1,200 m; 4-5 T/ha) for maize in Mumirwa and Abbey-Ife (1,600 m, 26-39 T/ha) for cassava in both regions. Similarly, fertilizer applications on the three crops referred to research recommendations [27].

Bean received $100 \mathrm{~kg}$ of DAP and $50 \mathrm{~kg}$ of $\mathrm{KCl}$ per ha. Two weeks before planting maize, an equivalent $750 \mathrm{~kg} / \mathrm{ha}$ of dolomitic lime was broadcasted followed by an application of $130 \mathrm{~kg}$ of DAP and $50 \mathrm{~kg}$ of KCl at planting, $18.5 \mathrm{~kg}$ of urea at the first weeding (20 days after planting) and $18.5 \mathrm{~kg}$ per ha at hilling. Cassava received $3 \mathrm{~T} / \mathrm{ha}$ of dolomitic lime two weeks before planting followed by an application of $10 \mathrm{~T} / \mathrm{ha}$ of cow manure, $52 \mathrm{~kg} / \mathrm{ha}$ urea, $32 \mathrm{~kg}$ DAP and $50 \mathrm{~kg}$ of $\mathrm{KCl}$ at planting. The remainder fertilizer $(52 \mathrm{~kg}$ of urea, $32 \mathrm{~kg}$ DAP and $50 \mathrm{~kg}$ of $\mathrm{KCl}$ ) was applied at heading. Maize weeding was done 3 weeks after planting. Hoeing was done after 6 weeks and hilling was executed at flowering.

Under the monoculture system, bean crop was planted in double rows $(40 \mathrm{~cm}$ x $20 \mathrm{~cm})$ spaced by $70 \mathrm{~cm}$. Maize crop was planted with $50 \mathrm{~cm}$ within and 75 between rows (26,666 plants/ha). Cassava crop was planted at 10,000 plants/ha with $1 \mathrm{~m} \mathrm{x} \mathrm{1m} \mathrm{spacing.} \mathrm{Under} \mathrm{the} \mathrm{intercropping} \mathrm{system,} \mathrm{bean} \mathrm{crop} \mathrm{was} \mathrm{planted} 48 \mathrm{~cm} \times 24 \mathrm{~cm}$ with $84 \mathrm{~cm}$ between double rows, whereas maize was planted at $90 \mathrm{~cm}$ x $60 \mathrm{~cm}$ spacing $(18,518$ plants/ha) and cassava at $1.2 \mathrm{~m} \times 1.2 \mathrm{~m}$ (6,944 plants/ha). Maize and cassava crops were planted between the bean double rows. The experiment was installed during season 2018A, on october 17, 2017 in Mumirwa and two days later in Kirimiro. Crop durations were as follow : a) in Mumirwa : 75 days for bean, 110 days fo maize and 365 days for cassava ; b) in Kirimiro : 90 days for bean, 150 days for maize and 455 days for cassava.These data will be used in the calculations of the Area $\mathrm{x}$ Time Equivalent Ratios (see Equations $2 \mathrm{a}$ and $2 \mathrm{~b}$ ).

Planting and harvest dates of maize and bean were the same in intercrop and sole crops. A second bean crop was planted in season 2018B (at the beginning of february), both in pure stands and in cassava-maize-bean intercrop. The sole maize crop was followed by a bean crop, a common rotational practice in Burundi.Consequently, throughout 
seasons 2018A and 2018B, the study covered two cassava crops (one sole crop and one intercrop), two maize crops (one sole crop and one intercrop) and five bean crops (three sole crops and two intercrops).

\subsection{Experimental Design}

The experiments were conducted in a completely randomized bloc design [28] with four replicates. Treatments were made of 4 plots: a plot of $9 \mathrm{~m} \mathrm{x} 9 \mathrm{~m}\left(81 \mathrm{~m}^{2}\right)$ with intercropped cassava-maize-bean, and three $9 \mathrm{~m} \times 3 \mathrm{~m}\left(27 \mathrm{~m}^{2}\right)$ plots for each of the monocrop for a total of $81 \mathrm{~m}^{2}$.

\subsection{Measured Parameters}

Evaluated parameters were yields, Land Equivalent Ratios (LER) and Area x Time Equivalent Ratios (ATER) [12, 15, 29-31], nutritive values (energy and proteins content) of the respective productions in intercrop and monocrop, together with their total and net returns, as well as their economic efficiency (V/C). For comparison purpose, total and net returns as well as the costs were evaluated in US dollars.

\subsubsection{Land Equivalent Ratio (LER)}

LER tries to answer the following question: how many units of land area are required to produce in monoculture system the same quantity of each crop produced by a unit area of intercrop? For that, a relative yield $\mathrm{RY}=\mathrm{y}^{\mathrm{i}} / \mathrm{y}^{\mathrm{m}}$ is calculated. It represents the yield of an interplanted species per unit area of intercropped land/yield per unit area of the same species in monoculture systems. The summation of relative yields over $\mathbf{n}$ interplanted species is the definition of LER.

The components of LER represent individual crop efficiency of yield production of each crop grown in mixture, relative to sole crop performance [10, 32-33].

$\mathbf{L E R}=\mathrm{RY}_{\mathrm{b}}+\mathbf{R Y m}+\mathbf{R Y _ { c }}$

LER indicates the efficiency of intercropping compared to monocropping in the use of the environnemental resources (water, $\mathrm{CO}_{2}$ and nutrients). When LER >1 the intercropping favors the growth and the yield of the species. LER > 1 indicates that more land is needed by the sole crop than the intercrop to provide equal quantities of the various products. As an example, LER=1.5 means $50 \%$ yield advantage of the intercrop over the sole crop (monocrop). In other words, LER > 1 means that monoculture systems use more land than the intercrop to provide equal quantities of the various products and the magnitude of LER quantifies the increase in biological efficiency achieved by interplanting [34]. On the contrary, LER value $<1$ indicates no intercropping advantage.

\subsubsection{Area x Time Equivalent Ratio (ATER)}

Although LER is the most used convention for intercrop and monocrop comparisons [4-13], it is considered incomplete because the cropping system duration (time) is not included in LER calculations [12]. Besides, when it is recognized that all cropping systems involve investments in land and in time, LER only takes into account the investisment in land. Thus, it ignores the possibility of one or two more short-cycled crops to be grown before harvesting the long-cycled crop [12]. Plus, LER does not take into account the duration of each component in the intercrop, meaning that land left unused after harvest of the short duration sole crop is not included in the calculation [35].

The conceptual inadequacy of LER was first brought to the attention of the scientific world by Hiebsch and McCollum (1987) [12] who then introduced the notion of Area xTime Equivalent Ratio (ATER) described by Equations $2 \mathrm{a}$ or $2 \mathrm{~b}$ below. These equations are conceptually analogous to Equation 1, but take into account crop duration as an essential component of intercropping biological efficiency. 
International Journal of Advances in Scientific Research and Engineering (ijasre), Vol 6 (4), April -2020

$\operatorname{ATER}=\left(t_{b} / t_{i}\right) R Y_{b}+\left(t_{m} / t_{j}\right) R Y_{m}+\left(t_{c} / t_{i}\right) R Y_{c}$

or

$\operatorname{ATER}=\left[\left(t_{b} x R Y_{b}\right)+\left(t_{m} \times R Y_{m}\right)+\left(t_{c} \times R Y_{c}\right)\right] / t_{i}$

Where $t_{b}=$ duration for bean crop, $t_{m}=$ duration for maize, $t_{c}=$ duration for cassava and the intercrop $\left(t_{i}\right)$. The specific crop durations are defined under 2.2.

Area $x$ Time Equivalent Ratio (ATER) is defined as « the ratio of number of hectare-days required in cassava, maize and bean monocrop to the number of hectare-days used in the cassava-maize-bean intercrop to produce identical quantities of each of the components. ATER $>1$ indicates that more area $\mathrm{x}$ time is needed by the sole crop, reflecting an intercrop area-time-use advantage. When ATER is close to one, there is no clear advantage or disadvantage of intercrop versus monocrop.

The ATER concept supposedly provides more realistic comparisons of yields advantage of intercropping over monocropping in terms of time taken by component crops in the intercropping systems [36]. However, it was advanced that ATER underestimates the biological efficiency when crops differ in growth duration, when planting immediately after harvest of preceding crop is not feasible [35].

\subsubsection{Nutrient Value}

Energy and protein content values of sole crops and intercrop productions were calculated based on FAO standards [37]. Respective protein contents of $100 \mathrm{~g}$ of produce is $22.6 \mathrm{~g}$ for bean, $9.3 \mathrm{~g}$ for maize and $1.2 \mathrm{~g}$ for cassava. The same quantity $(100 \mathrm{~g})$ of products provides 333 kilocalories for bean, 353 kilocalories for maize flour and 149 kilocalories for fresh cassava [37].

These FAO standards were used to calculate energy and protein values of tested crops in monoculture and intercropping systems. Generated data through the application of Equations 3 and 4 on monocrop and intercrop yields are shown in Table 4.

Total Energy $(\mathbf{k c a l} / \mathbf{h a})=\left(\mathbf{Y}_{\mathbf{b}} \times \mathbf{E}_{\mathbf{b}}\right)+\left(\mathbf{Y}_{\mathrm{m}} \mathbf{x E _ { m }}\right)+\left(\mathbf{Y}_{\mathbf{c}} \times \mathbf{E}_{\mathrm{c}}\right)$

Total Proteins $(\mathrm{kg} / \mathrm{ha})=\left(\mathbf{Y}_{\mathrm{b}} \times \mathbf{P}_{\mathrm{b})}+\left(\mathbf{Y}_{\mathrm{m}} \times \mathbf{P}_{\mathrm{m})}+\left(\mathbf{Y}_{\mathrm{c}} \times \mathbf{P}_{\mathrm{c}}\right)\right.\right.$

Where $\quad \mathrm{Y}=$ Yield $(\mathrm{kg} / \mathrm{ha})$ for bean $(\mathrm{b})$, maize $(\mathrm{m})$ and cassava $(\mathrm{c})$

$\mathrm{E}_{\mathrm{i}}$ and $\mathrm{P}_{\mathrm{i}}=$ Energy and protein content of respective crops [35].

\subsubsection{Economic Benefits}

We attempted to evaluate the comparative economic profitability of monoculture and intercropped systems based on yields scaled up to as per hectare. For that purpose, gross and net returns and economic efficiency were calculated according to equations 5, 6 and 7 .

Total return $/ \mathrm{ha}=($ yield A x price $A)+($ yield $B \times$ price $B)+($ yield $C \times$ price $C)$

Net return/ha $=$ total return - variable costs in intercrops and sole crops

Economic performance of the cropping systems $=\mathrm{V} / \mathrm{C}$ ratio

Where, $\mathrm{V}=$ monetary value and $\mathrm{C}=$ total costs. Any investment is considered profitable when its $\mathrm{V} / \mathrm{C}>2[38]$. 
In Mumirwa, practiced prices per $\mathrm{kg}$ of produce $(1 \mathrm{USD}=1,885.81)$ were 0.795 for bean, 0.530 for maize and 0.265 USD for fresh cassava. In Kirimiro, selling prices for bean, maize and fresh cassava were 0.530, 0.265 ad 0.159 USD, respectively. Practiced selling prices in Mumirwa were 67 to $100 \%$ higher compared to Kirimiro. Obtained results on economic benefits of the cassava, maize, bean monoculture systems and their intercrop in Mumirwa and Kirimiro agro-ecological zones are illustrated in Table 7.

\subsection{Statistical Analyses}

Measured parameters included LER and ATER values, total and net returns, economic efficiency (V/C ratio), energy and proteins values, together with soil characteristics (\%C, \% N, CEC, exchangeable $\mathrm{Ca}^{2+}, \mathrm{Mg}^{2+}$ and $\mathrm{K}^{2+}$ ). They were subjected to an analysis of variance (ANOVA I) using Genstat Discovery package VSN International [39]. When statistical significance was observed, mean separation was done with the Newman-Keuls method based on the Least Significant Difference (LSD). In parralel, when appropriate, pairwise comparisons were performed between intercropping and monoculture systems for the energy, proteins, total returns, costs, net returns LER and ATER using the Student t-test.

\section{RESULTS AND DISCUSSION}

\subsection{Soil Fertility}

Most studies on intercropping systems are focused on their biological efficiencies as defined by LER and ATER indices [4-13]. Very few investigations on intercropping have considered its effect on soil fertility dynamics [40]. Our study evaluated the changes in $\% \mathrm{C}, \% \mathrm{~N}, \mathrm{CEC}$ and exchangeable $\mathrm{Ca}^{2+}, \mathrm{Mg}^{2+}$ and $\mathrm{K}^{+}$before and after installation of bean, maize and cassava both under mono- and intercop.

Soil chemical characteristics of the study sites at the the beginning of the experiments are shown in Table 1. Compared to the Mumirwa experimental site, it can be observed that Kirimiro and Mumirwa sites had equivalent contents of $\% \mathrm{~N}$. However, \% C was higher $(+17 \%)$ in Kirimiro than in Mumirwa. On the other hand, the Mumirwa site is characterized by higher values of CEC $(+38 \%)$, and exchangeable $\mathrm{Ca}^{2+}(+50 \%), \mathrm{Mg}^{2+}(+41 \%)$ and $\mathrm{K}^{+}(+76$ $\%)$. This differential trend is in total coherence with the national soil fertility map described by Nduwimana et al., 2013 [41], with regard to $\mathrm{Ca}^{2+}, \mathrm{Mg}^{2+}$ and $\mathrm{K}^{+}$status. It is also easy to understand for $\mathrm{C}$, as the temperature in Kirimiro is lower than that in Mumirwa (See 2.1), leading to higher soil organic matter decomposition in the latter agroecological region.

Table 1. Selected chemical properties of soils in Mumirwa and Kirimiro experimental sites

\begin{tabular}{|c|c|c|c|c|c|c|}
\hline Experimental site & $\% \mathrm{C}$ & $\% \mathrm{~N}$ & CEC & $\mathrm{Ca}^{2+}$ & $\mathrm{Mg}^{2+}$ & $\mathrm{K}^{+}$ \\
\hline & \multicolumn{2}{|c|}{----- $\%$--- } & \multirow{2}{*}{\multicolumn{4}{|c|}{ 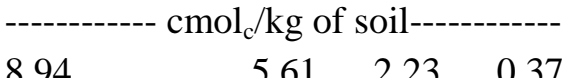 }} \\
\hline Mumirwa & 1.74 & 0.14 & & & & \\
\hline Kirimiro & 2.03 & 0.16 & 6.58 & 3.75 & 1.58 & 0.21 \\
\hline
\end{tabular}

Values of the soil chemical parameters indicated in Table 1 were used as a comparison basis to evaluate the effect of intercropping versus sole crops on soil $\% \mathrm{C}, \% \mathrm{~N}, \mathrm{CEC}$ and exchangeable exchangeable $\mathrm{Ca}^{2+}, \mathrm{Mg}^{2+}$, and $\mathrm{K}^{+}$(Table 2). Table 2 was generated by substracting values of $\% \mathrm{C}, \% \mathrm{~N}, \mathrm{CEC}$ and exchangeable basic cations from the original values indicated in Table 1.

Analysis of variance (ANOVA I) performed on latter data did not show any statistical significance $(\mathrm{p}>0.05)$ of intercropping over monoculture systems on $\% \mathrm{C}$, CEC and exchangeable $\mathrm{Ca}^{2+}, \mathrm{Mg}^{2+}$, and $\mathrm{K}^{+}$. For $\% \mathrm{~N}$ where a significant effect could be noticed $(\mathrm{p}<0.05)$, intercrop system was not significantly different from the monoculture system in Kirimiro. However, it was significantly higher than both the intercrop and the monoculture systems in Mumirwa. Neverthless, beyond statistics and generally speaking, it is apparent from Table 2 that intercropping cassava in Kirimiro, maize and bean was associated with an increase in $\% \mathrm{C}(+59 \%), \% \mathrm{~N}(+57 \%)$, exchangeable 
$\mathrm{Ca}^{2+}(+41 \%)$ and particlarly in $\mathrm{Mg}^{2+}(+430 \%)$, in comparison with monoculture systems. On the contrary, an inverse trend could be observed in Mumirwa mostly for CEC $(-188 \%)$ and exchangeable $\mathrm{Ca}^{2+}(-285 \%)$.

Table 2. Soil fertility variation under cassava-maize-bean sole and intercropping

\begin{tabular}{|c|c|c|c|c|c|c|c|}
\hline \multirow[t]{2}{*}{ AEZ/CS } & & $\% \mathrm{C}$ & $\% \mathrm{~N}$ & $\mathrm{CEC}$ & $\mathrm{Ca}^{2+}$ & $\mathrm{Mg}^{2+}$ & $\mathrm{K}^{+}$ \\
\hline & & \multicolumn{2}{|c|}{------- \% ------- } & \multicolumn{4}{|c|}{--------- cmolc/kg of soil-------- } \\
\hline \multicolumn{8}{|l|}{ Mumirwa } \\
\hline & Intercrop & 0.18 & $0.015 b$ & 0.41 & 0.33 & -0.03 & -0.01 \\
\hline & Sole crop & 0.16 & $0.011 b$ & 1.18 & 1.27 & 0.07 & 0.01 \\
\hline \multicolumn{8}{|l|}{ Kirimiro } \\
\hline & Intercrop & 0.43 & $0.055 \mathrm{a}$ & 2.83 & 2.09 & 0.48 & 0.02 \\
\hline & Sole crop & 0.27 & $0.035 \mathrm{ab}$ & 2.75 & 1.48 & 0.09 & -0.02 \\
\hline \multirow{2}{*}{\multicolumn{2}{|c|}{$\begin{array}{l}\text { LSD } \\
\text { Probability }\end{array}$}} & 0.30 & 0.027 & 2.61 & 2.86 & 0.62 & 0.15 \\
\hline & & $0.24^{\mathrm{NS}}$ & $0.016^{*}$ & $0.16^{\mathrm{NS}}$ & $0.60^{\mathrm{NS}}$ & $0.32^{\mathrm{NS}}$ & $0.91^{\mathrm{NS}}$ \\
\hline
\end{tabular}

Mean values with identical letters within the column are not statistically different at $\mathrm{p}<0.05$.

$\mathrm{NS}=$ non significant $(\mathrm{p}>0.05)$.

A number of accessed similar studies on the effect of intercropping systems on soil parameter dynamics reported a higher $\mathrm{N}$ accumulation, soil quality improvement and organic $\mathrm{C}$ sequestration [42]; soil microbial activity and structure [13, 15]. Similarly, Metwally et al. (2016) [43] advanced that maize and wheat increased yield and nutrient uptake when intercropped with peanut (Arachis hypogea L.) and faba bean (Vicia faba L.). In maize (Zea mays L.) soybean (Glycine max (L.) Merr.)) intercrop, Ming et al. (2019) [31] observed an increase in fertilizer-use and a decrease in $\mathrm{NH}_{3}$ volatilization risks by $45 \%$, resulting in safeguarding food supply while at the same time decreasing environmental pollution.

Besides the benefits of intercropping in terms of soil nutrient dynamics, the system is also associated with the reduction of soil erosion and runoff, higher water infiltration, retention and content, most possibly through soil structure improvement and increase in organic matter [13, 15]. This is particularly relevant with cassava crop considered the least efficient against soil erosion and runoff on sloping land [44]. This observation is confirmed by results reported in Burundi, where as much as $70 \mathrm{MT} / \mathrm{ha} /$ year of soil loss was recorded under cassava monocrop in the Mumirwa (Rushubi) agro-ecological zone [45].Consequently, intercropping cassava with other crops such as maize and bean could be considered as one of the mitigating soil erosion control technics available and easy to implement by Burundian farmers.

\subsection{Yields, Relative Yields and Competition Indices}

Compiled data on cassava, maize and bean both under sole crops and intercrop are summarized in Table 3 below. We must recall that both in Kirimiro and Mumirwa the study covered two cassava crops (one sole crop and one intercrop), two maize crops (one sole crop and one intercrop) and five bean crops (three sole crops and two intercrops). The different bean crops are identified in Table 3 as: season $A$ bean $\left(\right.$ Bean $\left._{A}\right)$, season B bean $\left(B^{2} n_{B}\right)$ and season $B$ bean $\left(\right.$ Bean $\left._{\mathrm{M}}\right)$ planted after season A maize harvest.

When compared to the potential yields advanced by ISABU research work (see 2.2), it appears that sole maize crops produced close (92-97\%) to yields reported by research for ZM 605 maize variety (Kirimiro) and Ecavel 1 maize variety (Mumirwa). The same was observed with Muhoro bean variety in Kirimiro where the sole crop could produce $92 \%$ of the potential yield of the variety. On the contrary, Muhoro bean variety produced half of its potential yield in Mumirwa, whereas the cassava Abbey-Ife variety showed very low yield compared to its potential yield in Mumirwa (33\%) and particularly in Kirimiro (16\%). We believe that these low yields of Abbey-Ife cassava variety impacted the profitability of the cropping systems more than maize and bean (see 3.4). 
An overview of cassava, maize and bean yields registered by national agriculture statistical services in Mumirwa and Kirimiro from 2015-2018 indicate even lower yields than those obtained in our experiment. According to official agriculture statistics, over four agriculture campaigns (2015-2018), cassava yielded an average of $8,200 \mathrm{~kg} / \mathrm{ha}$ in Mumirwa and 4,600 kg/ha in Kirimiro, maize yields were around $800 \mathrm{~kg} / \mathrm{ha}$ in both regions, while bean yields were $800 \mathrm{~kg} / \mathrm{ha}$ in Mumirwa and $670 \mathrm{~kg} / \mathrm{ha}$ in Kirimiro. The lesson to be drawn from these observations is that crop varieties released by research after their evaluation under experimental station conditions rarely express their full production potentials once under farmers managerial conditions.

Table 3. Sole and intercrop productions in Mumirwa and Kirimiro agro-ecological zones (kg/ha)

\begin{tabular}{|c|c|c|c|c|c|c|}
\hline$\underline{\mathrm{AEZ} / \mathrm{CS}}$ & & Cassava & Maize & $\underline{\text { Bean }}_{\underline{A}}$ & $\underline{\text { Bean }}_{\underline{B}}$ & $\underline{\text { Bean }}_{\underline{M}}$ \\
\hline \multicolumn{7}{|l|}{ Mumirwa } \\
\hline & Intercrop & 4846 & 3056 & 783 & 586 & - \\
\hline & Sole crop & 9907 & 4861 & 1060 & 1157 & 972 \\
\hline \multicolumn{7}{|l|}{ Kirimiro } \\
\hline & Intercrop & 3750 & 1327 & 1111 & 1651 & - \\
\hline & Sole crop & 4676 & 4306 & 1945 & 2130 & 2153 \\
\hline
\end{tabular}

Crop yields indicated in Table 3 allow to estimate relative crop yields defined as of the yield of an interplanted species per unit area of intercropped land over the yield per unit area of the same species in monocrop. Relative bean yield $\left(R Y_{b}=0.43-0.44\right)$ was similar independently of the agro-ecological zone, either Kirimiro or Mumirwa. However, relative yield of cassava was lower in Mumirwa $\left(\mathrm{RY}_{\mathrm{c}}=0.49\right)$ and higher in Kirimiro $(\mathrm{RY}=0.80)$. This high $\mathrm{RYc}$ value in Kirimiro is to be linked to the Abbey-Ife variety performance which was particularly lower as compared to its potential yield. An opposite trend was observed for maize relative yield which was higher in Mumirwa $\left(\mathrm{RY}_{\mathrm{m}}=0.63\right)$ and lower in Kirimiro $\left(\mathrm{RY}_{\mathrm{m}}=0.31\right)$, indicating some yield compensation between maize and cassava.

This biological phenomenon of crop yield compensation between cassava and maize was also recorded by Francis (1986) [17]. From this observation, the former investigator advanced that when interplanted species are in competition for the same limiting factor, a proportional increase in the yield of one species would cause a concomitant decrease in the yield of the other intercropped.

Application of Equation 1 came up with an equivalent value of LER=1.55, both in Mumirwa and Kirimiro study sites. It reveals that interspecific interaction or complementarity was greater than the competition, so that intercropping resulted in greater biological land-use efficiency $(+55 \%)$.

Similar calculations based on areas and times (Equations 2a and 2b) used by cassava, maize and bean sole crops in comparison with cassava-maize-bean intercrop gave ATER values close to unit: 1.03 in Kirimiro and 0.97 in Mumirwa. The obtained values close to 1 bring us to conclude that there is no cassava-maize-bean intercrop advantage over respective monoculture systems in terms of area $\mathrm{x}$ time efficiency, either in the Kirimiro or Mumirwa experiment. The absence of agro-ecological zone effect $(p>0.05)$ on LER and ATER indices in both study sites was confirmed by a pairwise Student t-test.

In an attempt to compare LER and ATER values obtained in our study with results generated by other reserarchers, a sample review of previous comparative works (Table 4) was done in a quite large range of countries: United Kingdom, China, India, Ethiopia, Denmark, Jordan, Egypt, US, Mozambique and Rwanda [4-13,43, 47-48]. 
International Journal of Advances in Scientific Research and Engineering (ijasre), Vol 6 (4), April -2020

Table 4. Sample of comparative LER and ATER values under different intercropping systems

\begin{tabular}{lllll} 
Cropping system $(\mathrm{CS})$ & Country & LER & ATER & Reference \\
\hline Wheat/bean & UK & 1.4 & - & Haymes and Lee (1990) [4] \\
Wheat/bean & UK & 1.29 & - & Bulson et al., 1997[5] \\
Wheat/chickpea & India & 1.55 & - & Banik et al., 2006[6] \\
Maize/bean & China & 1.34 & - & Li et al., 1999[7] \\
Bean/pea & Ethiopia & 1.53 & - & Abera and Feyisa, 2008[8] \\
Wheat/pea & Denmark & 1.34 & - & Ghaleyet al., 2005[9] \\
Oat/bean & UK & 1.34 & - & Willey et al., 1997[10] \\
Barley/vetch & Jordan & 1.76 & - & Sharaih et al., 2007[11] \\
Cotton/faba bean & Egypt & 1.91 & 1.04 & Metwally et al., 2016[43] \\
Maize/soybean & USA & 1.40 & $<1.1$ & Hiebsch\&McCollum, 1987[12] \\
Maize/pigeonpea & Mozambique & 1.1 & - & Rusinamhodzi et al. 2012[13] \\
Maize/cowpea & Mozambique & 1.7 & - & idem [13] \\
Maize/bean & Rwanda & 1.55 & 1.29 & Bramasubram. \& Sekayange, 1990[46] \\
Soybean/bean & Rwanda & 1.16 & 0.99 & idem \\
Bean/groundnut & Rwanda & 1.24 & 0.97 & idem \\
Bean/pigeon pea & Rwanda & 1.54 & 1.35 & idem \\
Cassava/sweet potato & Rwanda & 1.47 & 0.86 & idem \\
Maize/bean/sweet potato & Rwanda & 1.86 & 1.37 & idem \\
Cassava/maize/bean & Rwanda & 1.93 & 1.08 & idem \\
Cassava/maize/bean & Burundi & 1.55 & $0.97-1.03$ & This study \\
\hline
\end{tabular}

Most the consulted studies were based on double cropping systems involving cereals, legumes and commercial crops. Evaluated combination crops were: wheat (Triticum aestivum L.)/bean (Phaseolus vulgaris L.), wheat (Triticum aestivum L.)/chickpea (Cicer arietinum L.), maize (Zea mays L.)/bean (Phaseolus vulgaris L.), bean (Phaseolus vulgaris L.)/pea (Pisum sativumL.), wheat (Triticum aestivum L.)/pea (Pisum sativum L.), oat (Avena sativa L.)/pea (Pisum sativum L.), barley (Hordeum vulgare L.)/vetch (Vicia sativa L.), cotton (Gossypium hirsutum L.)/faba bean (Vicia faba L.), maize (Zea mays L.)/soyabean (Glycine max (L.) Merr., maize (Zea mays L.)/pigeonpea (Cajanus cajan (L.) Millsp (Huth)), and maize (Zea mays L.)/cowpea (Vigna unguiculata (L.) Walp)), soybean ((Glycine max (L.) Merr.)/bean (Phaseolus vulgaris L.), bean (Phaseolus vulgaris L.)/groundut (Arachis hypogea L.), bean (Phaseolus vulgaris L.)/pigeon pea ((Cajanus cajan (L.) Millsp (Huth)), cassava (Manihot esculenta Crantz)/sweet potato (Ipomea batatas L.), cassava (Manihot esculenta Crantz)/bean (Phaseolus vulgaris L.)/sweet potato (Ipomea batatas L.) and cassava (Manihot esculenta Crantz)/maize (Zea mays L.)/bean (Phaseolus vulgaris L.).

Table 4 shows elevated LER values for the following intercrops: barley/vetch, cotton/faba bean, maize/bean/sweet potato and cassava/bean/maize (Rwanda). Similarly, ATER values are higher for maize/bean, bean/pigeon pea and maize/bean/sweet potato intercrops, as outlined in Table 4. Otherwise, for most of the highlighted cropping systems, biological efficiencies were in the range of LER $(=1.55)$ and ATER $(=0.97-1.03)$ values obtained in our study.

Some of the relevant criticisms of LER and ATER are that the two biological and integrative concepts lack physiological or physical grounds [36]. As opposed to area (LER) and calendar time (ATER), most significant plant growth performance parameters are photosynthetically active radiation (PAR), light interception, radiation use efficiency (RUE), water use efficiency (WUE), accumulated thermal time, transpiration rate, nutrient uptake, harvest index (HI), yield components and dynamic of soil properties [36]. For a better understanding of the intercroping efficiency, most, if not all these listed parameters should be evaluated.

One can speculate on the effect of soil fertilization on LER or ATER indices, whether fertilizer application affect or not these biological indices. On this matter, contrasting results have been reported. For example, Zaffaroni et al. 1991[14] observed no significant fertilization effect on LER, whereas Abdelkader et al. (2018) [47] advanced that K fertilizerincreased LER and ATER. The potential effect of fertilization on intercropping efficiency is again one of the unexplored agriculture research area in Burundi. 


\subsection{Nutrive value}

Although we are totally aligned to Hiebsch and McCollum (1987) [12] statement that the starting point of any practical evaluation of intercropping should be a rational estimate of biological efficiency, in terms of LER and ATER concepts, we have the conviction that the most realistic concept of evaluating the advantages of intercrop versus monoculture systems, particularly in the context of Burundi subsistence agriculture, should be nutrition-based. Needless to stress out that for most Burundian farmers, obtaining a well-balanced diet for their family is more meaningful than any other intercropping benefits.

With the undeniable principle that most poor farmers in developping countries aspire to ensure food and nutrition security for their families, we evaluated the comparative nutrive benefits of cassava-maize-bean intercrop over their respective monoculture systems based on FAO standards [37]. Such an exercice generated energy (kilocalories/ha) and protein $(\mathrm{kg} / \mathrm{ha})$ data summarized in Table 5 .

The analysis of variance (ANOVA I) performed on energy and protein content does not show a clearly standing difference between the four combined tratments (site $\mathrm{x}$ cropping system). The highest energy yield was observed with the intercrop in Mumirwa site, while the highest protein yield was recorded in the Kirimiro intercrop. This is in line with the cassava and bean yields which were respectively higher in Mumirwa (cassava) and in Kirimiro (bean) as outlined in Table 3 above.

Table 5. Nutrive benefits (Energy and proteins) of cassava-maize-bean intercrop and sole crops.

\begin{tabular}{llll}
\hline AEZ/CP & & Energy $(\mathrm{kcal} / \mathrm{ha})$ & Protein $(\mathrm{kg} / \mathrm{ha})$ \\
Mumirwa & & & \\
& Intercrop & $22567759 \mathrm{a}$ & $652 \mathrm{ab}$ \\
& Sole crop & $14180561 \mathrm{~b}$ & $431 \mathrm{~b}$ \\
Kirimiro & & & $793 \mathrm{a}$ \\
& Intercrop & $19471213 \mathrm{ab}$ & $621 \mathrm{ab}$ \\
& Sole crop & $14300386 \mathrm{~b}$ & 258 \\
LSD & & 7794577 & $0.03 *$ \\
Probability & & $0.01 * *$ &
\end{tabular}

Mean values with identical letters within the column are not statistically different at $p<0.05$.

A complementary pairwise Student t-test demonstrated the statistical superiority $(\mathrm{p}<0.05)$ of the intercrop over the sole crops, independently of the study site. Compared to monoculture systems, the gains in energy associated with the intercropping system varied between +36 (Kirimiro) to $+59 \%$ (Mumirwa). A similar trend, though with lower values, was also observed for the protein content with an increase of $+28 \%$ and $+51 \%$, respectively in Kirimiro and Mumirwa experimental sites.

Although studies on the description of the Burundi agrarian systems can be documented [23-25], a literature search quest on quantified advantageous nutritive value of intercropping over monculture systems in terms of calories and proteins content was unsuccessful. We thus contend that this study might be one of the rare studies on this particular topic of intercropping in Burundi. However, although not directly related, a significant increase in volatile oil $(+4.7$ \%) was reported in intercropping caraway (Carum cavi L.)/onion (Allium cepa L.). On the other hand, Metwally et al. (2016) [43] and Zaeem et al. (2019) [48] observed an increase in chlorophyll content in intercrop comparatively to sole crops. Similar findings were reported on improvement in quality of intercropped wheat (Triticum aestivum L.) and cotton (Gossypium hirsutum L.), comparatively to their respective monoculture systems [49-50]. 


\subsection{Economic Benefits}

Debates have occurred on the comparative inadequacy of LER and ATER concepts, one of them being that LER overestimates the intercropping advantage over monoculture systems [12]. However, beyond the scientific world and set aside the nutrional benefit of intercropping, the most crucial advantages to farmers are based on comparative monetary values of the intercrop and monoculture productions.

Table 6 shows total (gross) returns, net returns, costs and V/C values (in US Dollars) associated with the tested cropping systems in Mumirwa and Kirimiro experimental sites. Data have been generated on the basis of Equations 5, 6 and 7 (see 2.6).

Table 6. Economic benefits (USD) of cassava-maize-bean intercrop and sole crops

\begin{tabular}{|c|c|c|c|c|}
\hline AEZ/CP & Total return & Costs & Net return & $\underline{\mathrm{V} / \mathrm{C}}$ \\
\hline \multicolumn{5}{|l|}{ Mumirwa } \\
\hline Intercrop & $3905 a$ & 3043 & $952 \mathrm{a}$ & $1.31 \mathrm{a}$ \\
\hline Sole crop & $2580 \mathrm{~b}$ & 3780 & $-119 c$ & $0.68 b c$ \\
\hline \multicolumn{5}{|l|}{ Kirimiro } \\
\hline Intercrop & $2413 b$ & 2533 & $-119 b$ & $0.95 \mathrm{ab}$ \\
\hline Sole crop & $1729 b$ & 3072 & $-1343 c$ & $0.56 c$ \\
\hline LSD & 1037 & & 1037 & 0.37 \\
\hline Probability & $0.005 * *$ & - & $0.002 * *$ & $0.006^{* *}$ \\
\hline
\end{tabular}

Mean values with identical letters within the column are not statistically different at $\mathrm{p}<0.05$.

1 US Dollar = 1,885.81 Burundi Francs.

The highest total returns (about 4,000 USD per hectare) was obtained with the cassava-maize intercrop in the Mumirwa agro-ecological zone $(\mathrm{p}<0.01)$. Otherwise, there was no significant differences between the other three treatments: the sole crop in Mumirwa and the intercrop as well as the sole crop in Kirimiro. Estimates of net returns indicate negative values for the monoculture systems in Mumirwa and both the monocrop and the intercop in Kirimiro. The only positive return (about 950 USD) was recorded with the cassava-maize-bean intercrop in Mumirwa, which had also the highest total return as outlined above. All treatments were characterized by $\mathrm{V} / \mathrm{C}<2$, indicating that both the intercropping and the monoculture systems are not economically efficient with reference to FAO standards [38].

A t-test performed on total and net returns indicated a statistical superiority $(\mathrm{p}<0.05)$ of the intercrop over sole crops, independently of the study site factor. The opposite was observed with the costs which were significantly higher $(\mathrm{p}<$ $0.001)$ in the monoculture system as compared with the intercroppping system, and so both in Mumirwa (+ $24 \%)$ and Kirimiro $(+21 \%)$ experimental sites.

Detailed \% distribution of major cost posts is illustrated in Table 7. It can be observed from Table 7 that the two costiest posts and thus limiting factors of profitability are fertilizers application+pesticides application and labor. The two posts account for 60-64 and 65-68 \% of the total costs, respectively in Mumirwa and Kirimiro experimental sites. Thus, any attempt to maximize the profitability of the intercropping as well as the monoculture systems must minimize the costs of chemical (fertilizer and pesticides) inputs and labor. 
Table 7. Percentage (\%) distribution of costs under monocrop and intercrop

\begin{tabular}{|c|c|c|c|c|c|}
\hline AEZ/CP & Land & Labor & $\underline{\text { Seeds }}$ & Fertilizers & Stakes \\
\hline \multicolumn{6}{|l|}{ Mumirwa } \\
\hline Intercrop & 21.5 & 29.8 & 6.0 & 34.4 & 8.3 \\
\hline Sole crop & 17.3 & 22.1 & 10.7 & 37.4 & 12.5 \\
\hline \multicolumn{6}{|l|}{ Kirimiro } \\
\hline Intercrop & 17.3 & 28.0 & 7.2 & 41.3 & 6.2 \\
\hline Sole crop & 11.8 & 19.4 & 13.1 & 46.1 & 9.6 \\
\hline
\end{tabular}

Climbing stakes for beans represent an average $9 \%$ of the total costs accross experimental sites and cropping systems. This post could be minimized if one uses maize stalks after crop harvest or agroforestry species (Calliandra calothyrsus Meisn) installed on live hedgerows for soil erosion control. Another alternative would be to take into account the cassava and bean fresh leaves generally harvested and consumed as legumes by farmers during crop growth. These could be some of the operations to consider in an attempt to increase the global profitability of the cassava-maize-bean intercropping.

Availability of labor, markets and prices are some the economic and social factors controlling profitability of any enterprise. In Burundi, practiced prices on farmers products are considered low, whereas costs, particularly those relative to chemical inputs (e.g. fertilizers and pesticides) and labor are high, as mentionned above. Consequently, net returns are very low or even negative as we observed in our study. On this sole basis, economists would consider the intercropping system not attractive. Why then the intercropping system is so widespread among subsistance farmers in Burundi and elsewhere in countries of similar socio-economic conditions? Subsistence farmers surely have reasons to adopt such complex cropping systems which, some investigators do not hesitate to label as revolutionary approaches to manage limited agriculture land and simultaneously ensure household food and nutrional security [17]. On that aspect, one needs to stress out that most farmers do not account for familiy labor because opportunities to value it outside the family nucleus are rare [23-25].

Although results obtained in our particular study indicated that the cassava-maize-bean intercropping did not prove profitable in terms of net returns and economic efficiency, other similar studies have demonstrated otherwise. For example, Onyang et al. (2017) [51] reported positive economic benefits of maize (Zea mays L.) and Chili (Capsicum annum L.) intercropping systems as compared to sole crops. Apparently, this is commonly observed for marketoriented crops such as Chili (Capsicum annum L.), cotton (Gossypium hirsutum L.), and other crops for which the prices are regulated $[43,47,49]$.

Unfortnately, this is far from being the case in Burundi. As outlined before, prices of agriculture products are very low, different from region to region and season dependent. Moreover, because most subsistence farmers have no or little access to conservation facilities added to family needs pressure with regard to money and various consumable items, they are obliged to sell their products at low prices just after harvest.

Viewed on a broader perspective, although the intercropping system might not be economically profitable, as in our case study, it integrates many wide range advantages or benefits which have been largely documented $[6,11,13,30$ 31, 36, 48, 51-54]. These benefits include land productivity and yield stability, nutrition and food security, soil conservation, global crop resilience, environment health in terms of soil, water and air quality, bio-remediation (phytoremediation), increased use of solar radiation, water use efficiency due to decreased evaporation, increased nutrient uptake, decreased weeds pressure and subsequently weeding labor investment, mitigating climatic change, Csequestration and global warming mitigation, microbial abundance and diversity. All the above benefits lead to sustainable agriculture [55]. 
In brief, this study demonstrated that the cassava-maize-bean intercropping is interesting on many aspects such as: land-use efficiency (LER), nutrition and diversification of diet (energy and proteins), as well as soil quality improvement in terms of $\% \mathrm{~N}, \% \mathrm{C}, \mathrm{CEC}$ and exchangeable $\mathrm{Ca}^{2+}$, and $\mathrm{Mg}^{2+}$, most notably in Kirimiro agro-ecological zone (Table 2).

However, one must stress out that the intercropping system is subject to many challenges, one of them being the urgence to breeding programs to propose genotypes/phenotypes suitable to intercropping, in terms of compatibility (absence of allelopathy), favorable aerial architecture or rooting system stratification to avoid intercropped plants competition for growth resources (water, $\mathrm{CO}_{2}$, nutrients). Competition is the factor affecting growth and yield of plant species intercrop comparative to pure stands. Higher intercropped plant yields are achieved when interspecific competition is lower than intra-specific [49].We believe that this is the major orientation, Burundi agriculture research should focus on: having the right picture and the rationale behind the current cropping systems and, from there, propose to farmers adapted technologies and management systems which respond to their needs, aspirations and constraints (time and land).

This is a major challenge, given the complexity of intercropping research due to combinations of many and various factors which can be summarized in two major groups:(i) site-specific factors which include climate, socio-economic constraints, soil properties, labor and time constraints; (ii) field operations factors like land preparation, tillage, weed and pest control, fertilization, dates of planting, patterns/spatial arrangement, densities, morphological and physiological aspects of intercropped species and cultivars $[5,7,8,18,34,56-58]$.

To be effective, research on intercropping has to bring together diversified and specialized scientists such as ecologists, breeders, agronomists and social scientits, as this research field should be farmer-targeted and farmercentered. Unfortunately, most of time, this wide but complementary competencies and approaches are lacking, particularly in Burundi.

\section{CONCLUSION AND PERSPECTIVES}

Intercropping is widespread among Burundian farmers subjected to high population pressure on limited agriculture land. Under this condition, unless there is a revolutionary socio-economic mutation, this cropping system will continue to dominate the Burundi small scale agriculture landscape for millions of households with limited resources. For these categories of farmers, intercropping provides food and income, while minimizing risk of crop failure consecutive to climatic vagaries (high rainfall and drought) and/or pests and diseases.

Despite the undeniable predominance of varied intercropping systems in the current Burundi agriculture sector, they rarely meet the interest of the scientific agriculture community. Working closely and together with the farmer in a participatory and mutually learning approach, ADISCO/UPH research teams get better and clearer insight of what the associated farmer is facing and, from there mutually come up with practical and consensual solutions. With this developmental philosophy in mind, this farmer-oriented organization evaluated the comparative advantages of cassava-maize-bean intercropping system, relative to corresponding monoculture systems under two major Burundi agro-ecological zones, Mumirwa and Kirimiro.

This research work assessed cassava-maize-bean effects on soil fertility, biological efficiency (LER and ATER), nutrient value (energy, proteins) and economic benefits (total and net returns, value/cost ratio). The study demonstrated that the cassava-maize-bean intercropping is associated with many benefits, such as: land-use efficiency (LER), nutrition and diversification of diet (energy and proteins), as well as soil quality improvement (\% C, \% $\mathrm{N}$, $\left.\mathrm{CEC}, \mathrm{Ca}^{2+}, \mathrm{Mg}^{2+}\right)$.

Specifically, cassava-maize-bean intercropping resulted in greater biological land-use efficiency $(+55 \%)$, increase in soil organic $\mathrm{N}$ and nutritional added values. Compared to monoculture systems, the gains in energy associated with the intercropping system varied between +36 (Kirimiro) and $+59 \%$ (Mumirwa), while those of protein content ranged from $+28 \%$ and $+51 \%$, respectively in Kirimiro and Mumirwa. However, the study revealed that neither the 
intercropping nor the monoculture systems are economically efficient, with reference to generated net returns and economic efficiency $(\mathrm{V} / \mathrm{C}<2)$. Overall, we conclude from our study that, in the short tem, for most farmers, obtaining a well-balanced and regular diet for their family is more meaningful than any other intercropping benefits.

Although spontaneously adopted by Burundi small scale farmers, cassava-maiaze-bean intercropping is subject to many challenges. One of them is the urgence to Burundian agronomic research, breeding and selection programs to propose genotypes/phenotypes suitable to intercropping, in terms of crop compatibility, favorable aerial architecture (morphology) or rooting system stratification to avoid intercropped plants competition for growth resources. Concomittantly, studies on optimal planting densities and adapted fertilizers application of intercrops would improve our understanding of the cassava-maize-bean intercropping systems in Burundi.

\section{REFERENCES}

1. Gouvernement du Burundi. 2011. Cadre Stratégique de la croissance et la Lutte contre le Pauvreté Deuxième Génération. Bujumbura, 145 p.

2. ISTEEBU, 2013-2018. Enquêtes Nationales Agricoles du Burundi (ENAB). Résultats de campagnes agricoles 2013-2018. Bujumbura.

3. Dapaah, H.K., N. Asafu-Agyei, S.A. Ennin and C. Yamoah. 2003. Yield stability of cassava, maize, soyabean and cowpea intercrops. Journal of Agricultural Science. Volume 140 (1): 73-82.

4. Haymes R. and H.C. Lee. 1999. Competition between autumn and spring planted grain intercrops of wheat (Triticum aestivum) and field bean (Vicia faba). Field Crops Research 62: 167-176.

5. Bulson, H.A.J., R.N. Snaydon and C.E. Stopes. 1997. Effects of plant density on intercropped wheat and field bean in an organic farming system. Journal of Agricultural Sciences 128: 59-71.

6. Banik, P. A. Midya, B.K. Sarkar and S.S. Ghose. 2006. Wheat and chickpea intercropping system in an additive series experiment, advantages and weed smothering. European Journal of Agronomy 24: 325-332.

7. Li L. S. Yad, X.Li and P. Christie. 1999. Interspecific complementary and competitive interactions between intercropped maize and faba bean. Plant and Soil 212: 105-114.

8. Abera T. and D. Feyisa. 2008. Faba bean and field pea seed proportion for intercropping system in Horro highlands of Western Ethiopia.African Crop Science Journal 16: 243-249.

9. Ghaley, B.B. H. Hauggaard-Nielsen, H. Hogh-Jensen, E.S. Jensen. Intercropping of wheat and pea as influenced by nitrogen fertilization. Nutrient Cycling in Agroecosystems 73: 201-212.

10. Willey, R.W., N. Mohammed and S. Morse. 1997. Factors affecting compensation inintercropping when one component fails. Tropical Agriculture 74: 313-316.

11. Sharaiha, R.K. and F.M. Ziadat. 2007. Alternative cropping systems to control soil erosion in arid and semiarid areas of Jordan. African Crop Science Proceedings Vol 8: 1559-1565.

12. 12. Hiebschn C.K. and R.E. McCollum. 1987. Area $x$ time equivalency ratio: A method for evaluating the productivity of intercrops. Agron. J. $79: 15-22$.

13. 13. Rusinamhodzi, L. M. Corbels, J. Nyamangara and K.E. Giller. 2012. Maize-grain legume intercropping is an attractive option for ecological intensification that reduces climatic risk for smallholders' farmers in Central Mozambique. Field Crops Research 136: 12-22.

14. Zaffaroni E., A.F.M. Vasconcelos and E.B. Lopes. 1991. Evaluation of intercropping cassava/corn/beans (Phaseolus vulgaris L.) in northeast Brazil. J. Agronomy \& Crop Science 167: 207-212.

15. Knörzer, H., S. Graeff-Hönninger, B. Guo, P. Wang and W. Claupein.2009. The rediscovery of intercropping in China: A traditional cropping system for future Chinese Agriculture - A review. In Climate change, intercropping, Pest Control and beneficial microorganisms. pp.13-44. Springler.

16. Andrews, D.S., A.H. Kassam. 1976. The importance of multiple cropping in increasing world food supplies. In: Multiple cropping (R.I. Papendick, P.A. Sanchez and G.B. Triplett, eds.). Amer. Soc. Agron. Spec. Publ. 27: 1-10.

17. Francis, C.A (Ed.). 1986. Multiple Cropping. Macmillan Publishing Company. 866 Third Avenue, New York, NY 10022.

18. Spio, K. 2010. Intercropping - The hidden revolution: A solution to land scarcity and household food security. 
Agrekon. Volume 35 (4): 266-270.

19. Bradfield, S. 1986. Sociocultural factors in multiple cropping. p. 267-284. In Francis C.A. (Ed.). Multiple cropping. Macmillan Publishing Company. 866 Third Avenue, New York, NY 10022.

20. Lynam, J.K., J.H. Sanders and S.C. Mason. 1986. Economics and risk in multiple cropping. p. 250-266. In Francis C.A (Ed.). 1986. Multiple Cropping. Macmillan Publishing Company. 866 Third Avenue, New York, NY 10022.

21. Hart, R.D. 1986. Ecological framework for multiple cropping research. p. 40-56. In Francis C.A (Ed.). 1986. Multiple Cropping. Macmillan Publishing Company. 866 Third Avenue, New York, NY 10022.

22. Doubi, B.T.S., K. Kouassi, K. L. Kouakou, K. K. Koffi, J.P. Baudoin\& B. I. A. Zoeo. 2016. Existing competitive indices in the intercropping system of Manihot esculentaCrantz and Lagenaria siceraria (Molina) Standley. Journal of Plant interactions. 11(1) : 178-185.

23. Mertens, A. 1984. Contribution à la connaissance des regions naturelles du Burundi: le système traditionnel d'exploitation au Burundi. ISABU, Publication $\mathrm{N}^{\circ} 65$.

24. Verhaegen, E., J. Degand and L. D'Haese. 1991. Amélioration des systèmes d'exploitation agricole traditionnels du Burundi. Projet SYSTRA. Faculté des Sciences Agronomiques, Université du Burundi. Administration Générale de la Coopération AU Développement (Belgique).

25. Cochet, H. 2004. Agrarian dynamics, population growth and resource management: the case of Burundi. Geojournal 60: 111-122.

26. ISTEEBU. 2015. Annuaire des Statistiques de l'Environnement du Burundi. 60 p.

27. MINEAGRIE, 2016. Fiches techniques harmonisées des cultures de haricot, maïs et manioc au Burundi. 6 p. (cumulées).

28. Dagnélie, P. 1987. Théorie et méthodes statistiques, application agronomique. Volume 2. Presses agronomiques de Gembloux, Belgique. 463 p.

29. Francis, C.A. 1989. Biological efficiencies in multiple-cropping systems. Advances in Agronomy 42: 1-42.

30. Mousavi, S.R. and H. Eskandari. 2011. A general overview on intercropping and its advantages in sustainable agriculture. J. Appl. Environ. Biol. Sci. 1 (11): 482-486.

31. Ming, F.K., A.P.K. Tai, T. Yong, X. Liu and H-M. Lam. 2019. Co-benefits of intercropping as a sustainable farming method for safeguarding both food security and air quality. Environmental Research Letters. Volume 14 (4). IOP Publishing Ltd.

32. Mead, R. and R.W. Willey. 1980. The concept of a land equivalent ratio and advantages in yields from intercropping. Experimental Agriculture 16: 217-228.

33. Mead, R., 1986. Statistical methods for multiple cropping. p. 317-350. In Francis C.A (Ed.). 1986. Multiple Cropping. Macmillan Publishing Company. 866 Third Avenue, New York, NY 10022.

34. Hiebsch, C.K. F. Tetio-Kagho, A.M. Chirembo and P. Gardner. 1995. Plant density and soybean maturity in a soybean-maize intercrop. Agron. J. 87: 965-969.

35. Fukai, S. 1993. Intercropping bases of productivity. Field Crops Research 34: 239-245.

36. Yakuza, I. 2011. Review of some methods of calculating intercrop efficiencies with particular reference to the estimates of intercrop benefits in wheat/bean faba system. International Journal of Biosciences (IJB). Vol 1 (5): $18-30$.

37. FAO. 2005. Guide de nutrition familiale. Rome.

38. Young, W.Y. 1989. Méthode d'enquête sur la gestion des entreprises agricoles. FAO, Rome. 246 p.

39. Buysse, W., R. Stern and R. Coe.2004. GenStat Discovery Edition fo Everyday use. ICRAF. Nairobi, Kenya. $114 \mathrm{p}$.

40. Hauggard-Nielsen H., J. Kinane, J. Jørnsgaard and E.S. Jensen. 2008. Grain legume-cereal intercropping: the practical application of diversity, competition and facilitation in arable and organic cropping systems. Renewable Agriculture and Food Systems 23: 3-12.

41. Nduwimana, O., Z. Nzohabonayo, C. Hicintuka et M. Nibasumba. 2013. Cartographie de la fertilité des sols et des besoins des principales cultures vivrières en éléments nutritifs. PAN PNSEB. $110 \mathrm{p}$.

42. Cong, W-F., E.L.L. Hoffland, J. Six, J.H. Sun, X-G. Bao, F-S. Zhang and W.V. Der Werf. 2015. Intercropping enhances soil carbon and nitrogen. Experimental Physiology 21 (4): 1715-1726. 
43. Metwally, A.A., A.A. Abuldahab, M.N. Shereif and M.M. Awad. 2016. Productivity and Land Equivalent Ratio of intercropping cotton with some winter crops in Egypt. American Journal of Experimental Agriculture $14(1): 1-15$.

44. Lijima, M., Y. Izumu, E. Yuhadi, S. Sunyoto and W.S. Ardjasa. 2004. Cassava-based intercropping systems on Sumatra Island in Indonesia: Productivity, Soil erosion and rooting zone. Journal Plant Production Science. Vol (7): 347-355.

45. Duchaufour H., Bizimana M., Mikokoro C., 1992. Les acquis de la recherche à l'ISABU en matière de protection et de restauration des sols. Séminaire sur l'érosion au Burundi, 24 p.

46. Barasubramanian, V. and Sekayange, L. Area HarvestsEquivalency ratio for measuring efficiency in multi-season intercropping. Agron. J. 82: 512-522.

47. Abdelkader, M.A.I., H.G.ZyadaandE.A. Bardisi. 2018. Evaluation of yield components and some competitive indices between Caraway and onion plants as affected by intercropping system under different Potassium fertilizer rates. Zagazig J.Agric. Rese. Vol. 45 (6A):1925-1939.

48. Zaeem, M., M. Nadeem, T.H. Pham, W. Ashiq, W. Ali, S.S. M. Gilani, S. Elavarthu, V. Kavanagh, M. Cheema, L. Galagedara and R. Thomas. 2019. The potential of corn-soybean intercropping to improve the soil health status and biomass production in cool climate boreal ecosytem. Scientific Reports 9, 13148. https://doi.org/10.1038/s41598-019-49558-3.

49. Zhang L., W. van der Werf, S. Zhang, B. Li and J.H.J. Spiertz. 2007. Growth, yield and quality of wheat and cotton in relay strip intercropping systems. Field Crops Research 103: 178-188.

50. Tosti, G. and M. Guiducci. 2010. Durum wheat-faba bean temporary intercropping: effects of nitrogen supply and wheat quality. European Journal of Agronomy 33: 157-165.

51. Onyang, C., K. Wu, T.an, J. He, S. Zi, Y. Yang and B. Wu. 2017. Productivity, economic and environmental benefits in intercropping of maize with chili and grass. Agronomy Journal J. 109 (5): 2407-2414.

52. Brooker, R.W., A.E. Bennett, W-F. Cong, T.J. Daniell, T.S. George, P.D. Hallett, C. Hawes, P.P.M. Iannetta, öH.G. Jones, A.J. Karley, L. Li, B.M. McKenzie, R.J. Pakeman, E. Paterson, C. Schröb, J. Shen, G. Squire, C.A. Watson, C. Zhang, F. Zhang, J. Zhang and P.J. White. 2015. Improving intercropping: a synthsesis of research in agronomy, plant physiology and ecology. New Phytologist 206: 107-117.

53. Pradhan, A. A. Thakur, A. Sao and D.P. Patel. 2014. Biologicalefficiency of intercropping in finger millet (Eleusina coracana L. Gaertn) under rainfed condition. International Journal of Current Microbiology and Applied Sciences. Vol. 3(1): 719-723.

54. Sun, M., D. Fu, Y. Teng, Y. Shen, Y. Luo, Z. Li and P. Christie. 2011. In situ Phyto-remediation of PAHcontaminated soil by intercropping alfalfa (Medicago sativa L.) with tall fescue (FestucaarundinaceaSchreb.) and associated microbial activity. Journal of Soils and Sediments 11(6): 980-089.

55. Lithourgidis, A.S., C.A. Dordas, C.A. Damalas, D.N. Vlachosterigios. 2011. Annual intercrops: an alternative pathway for sustainable agriculture. Australian Journal of Crop Science 5(4) : 396-410.

56. Barker, T.C. and C.A. Francis. 1986. Agronomy of multiple cropping systems. p. 181-182. In Francis C.A (Ed.). 1986. Multiple Cropping. Macmillan Publishing Company. 866 Third Avenue, New York, NY 10022.

57. Confalone, A., J.I. Lizaso, B. Ruiz-nogueira, F. Lopez-Cedron and F. Sav. 2010. Growth, PAR use efficiency and yield component of field grown Vicia faba L. under different temperature and photo periods regimes. Field Crops Research 115: 140-148.

58. Dhima, K.V. A.S. Lithourgidis, I.B. Vasilakoglou and C.A. Dordas. 2007. Competition ndices of common vetch and cereal intercrop in two seeding ratios. Field Crops Research 100: 249-256. 